\title{
First evidence of coral bioconstructions in the Monte Postale succession (Lower Eocene of Lessini Mts., Veneto, northern Italy)
}

\author{
Cesare Andrea Papazzoni $\left({ }^{a}\right)$, Alessandro Vescogni $\left({ }^{a}\right)$, Francesca Bosellini $\left({ }^{a}\right)$, Luca Giusberti $\left({ }^{b}\right)$, \\ Guido Roghi $\left({ }^{\mathrm{c}}\right)$ \& Stefano Dominici $\left({ }^{\mathrm{d}}\right)$
}

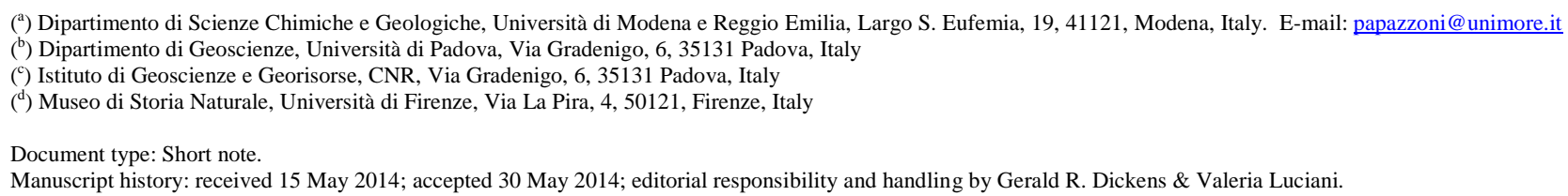

KEY WORDS Alveolina, Bolca Lagerstätten, coral reefs, dasycladacean algae, Eocene, northern Italy.

The world-famous Fossil-Lagerstätten of the Bolca area have long been interpreted (e.g., Sorbini, 1972) as deposited in a carbonate platform setting, within an intra-platform depression or basin, protected from the open-marine environment by some kind of threshold (Papazzoni \& Trevisani, 2006; Schwark et al., 2009). The presence of corals, both in the Pesciara di Bolca site and in the nearby Monte Postale succession, suggests that the threshold may be formed by some kind of bioconstructed margin. Although the occurrence of a possible "reef" environment has been suggested by the composition of the fish fossil assemblage (Landini \& Sorbini, 1996; Belwood, 1996; Bellwood et al., 2014), no direct observation of a preserved coral bioconstruction has ever been reported for the Bolca area.

The Monte Postale succession represents the most complete stratigraphic record of the area, tracing the depositional history before and after the deposition of the laminated limestones containing the fish fauna of the Bolca Lagerstätten. Considering that the last detailed study of the area dates from the beginning of the last century (Fabiani, 1914), a new survey was necessary to update the knowledge of both paleoecological and biostratigraphic aspects. During this survey, some massive limestone bodies were observed, and their in situ position within the stratigraphic succession was ascertained. They turned out to be small bioconstructions, a few metres thick, with abundant coral colonies in growth position or preserved as broken rubble. Detailed field mapping and facies analysis of several of these structures allowed the identification of a discontinuous belt along the northern side of the Monte Postale, and to recognize four different facies types:

- Facies A: Coral boundstone. It forms the bulk of the massive outcrops (Fig 1a, b). Dominant genera are Goniopora, Stylophora, Actinacis, Goniastrea, Astrocoenia and Astreopora, while Stylocoenia, Siderastrea, Pachygyra and Caulastrea are subordinate. Corals are often encrusted by foraminifera and coralline red algae. A fine-grained micritic wackestone fills the small cavities among the colonies, associated also with a coarser Alveolina packstone. In both cases, fragments of dasycladacean green algae represent one of the most important bioclastic components.

- Facies B: Stratified Alveolina grainstone. This facies represents the sediment above and within Facies A (Fig 1a). Associated with the larger forams, coral fragments are also abundant.

- Facies C: Well-bedded, fine-grained packstone. These sediments onlap on the south-eastern side of the massive outcrops (Fig. 1b), and mainly contain small fragments of Alveolina and corals. The stratified packstone succession is sometimes interrupted by the presence of fine-grained, laminated strata, characterized by few fossil remains and a darker colour related to the abundant presence of organic matter.

- Facies D: Nummulites packstone. This facies crops out along the northern boundary of Facies A. Nummulites are also associated with Alveolina and abundant coral fragments.

The rich Alveolina assemblages of Facies $\mathrm{A}$ and $\mathrm{B}$ contain, among others, Alveolina cremae, A. aff. croatica, $A$. decastroi, A. cf. dainellii, and A. distefanoi, that date the depositional system to SBZ 11 (Middle Cuisian, Lower Eocene) of Serra-Kiel et al. (1998).

The preliminary interpretation of these four facies allows recognition of distinct paleoenvironments. The massive carbonates of Facies A, dominated by corals and associated with a remarkable amount of dasycladacean algae, indicate the presence of a wave-resistant structure, represented by a discontinuous alignment of small coral bioconstructions that developed in a very shallow-water environment, located within the upper part of the photic zone. This interpretation is also supported by the coalescence of these buildups with the sediments of Facies B, whose Alveolina grainstone also suggests deposition at some meters of depth. Hence, the paleoenvironment of Facies A and B may be interpreted as a 

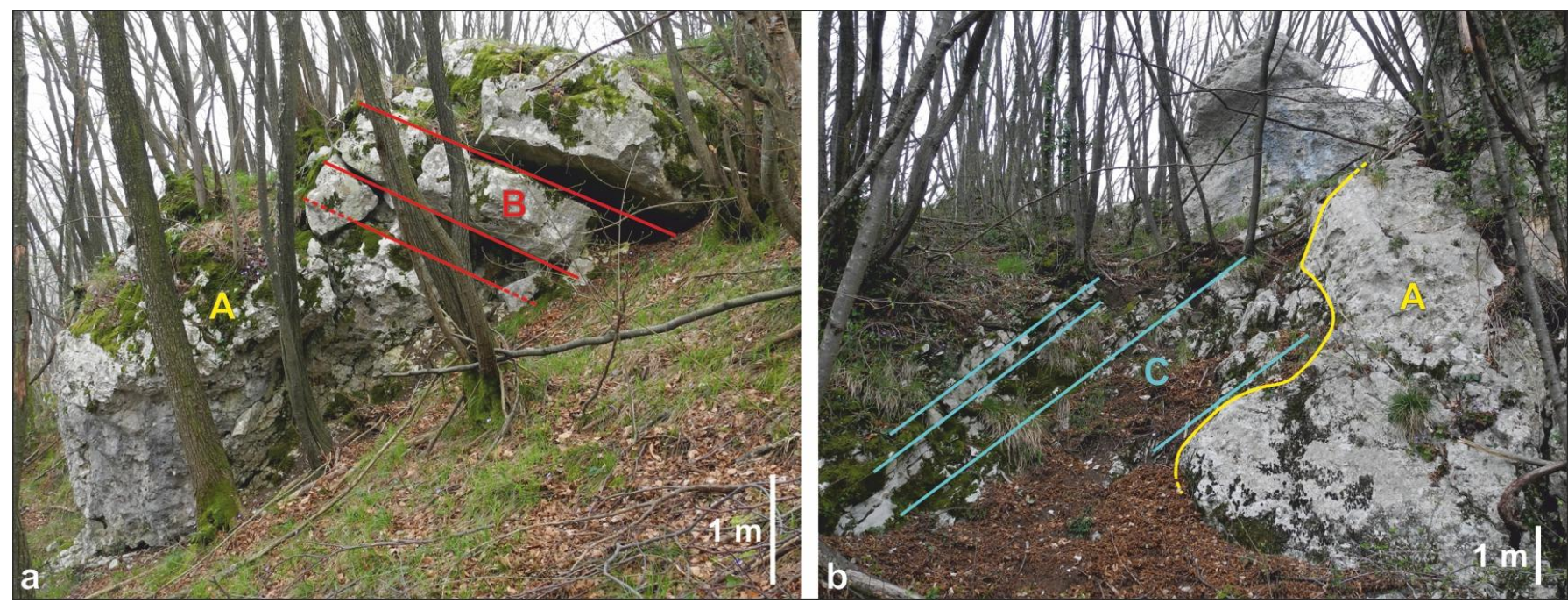

Fig.1 - a) Stratigraphic relationships between the massive boundstone of Facies A and the stratified packstone of Facies B; b) onlap of the bedded limestone of Facies $\mathrm{C}$ on a massive outcrop of Facies A.

belt of small patch reefs and sand bodies, delineating a threshold that created a protected lagoon extended towards the south-east. Facies $\mathrm{C}$ was deposited in this low-energy environment, and the presence within the fine-grained packstone strata of finely-laminated levels, also rich in organic matter, could indicate the occurrence of periodic dysoxic events during the evolution of the Monte Postale lagoon. Such events, if proven, might be related to the deposition of the laminated limestones that characterize the Konservat-Lagerstätten of the Pesciara di Bolca and Monte Postale. On the opposite side, along the northern boundary of the coral belt, sediments are mainly represented by the Nummulites packstone of Facies D, suggesting more open, normal marine conditions.

These results, although very preliminary, describe for the first time the coral-bioconstructed system that allowed the formation of one of the most important Eocene FossilLagerstätten in the world. Moreover, some components of the reef biota, such as the abundant dasycladacean algae of Facies A, are indeed rare in the Eocene limestones of northern Italy and have never been previously reported from this area.

Research supported by grants PRIN 2010 "Past Excess $\mathrm{CO}_{2}$ worlds: biota responses to extreme warmth and ocean acidification".

\section{REFERENCES}

Bellwood D.R. (1996) - The Eocene fishes of Monte Bolca: the earliest coral reef fish assemblage. Coral Reefs,
15 (1), 11-19.Bellwood D.R., Goatley C.H.R., Brandl S.J. \& Bellwood O. (2014.) - Fifty million years of herbivory on coral reefs: fossils, fish and functional innovations. Proc. R. Soc. B, 281, 20133046.

Fabiani R. (1914) - La serie stratigrafica del Monte Bolca e dei suoi dintorni. Mem. Ist. Geol. R. Univ. Padova, 2, 223-235.

Landini W. \& Sorbini L. (1996) - Ecological and trophic relationships of Eocene Monte Bolca (Pesciara) fish fauna. In: Cherchi, A. (Ed.), Autecology of selected fossil organisms: Achievements and problems. Boll. Soc. Paleont. It., Spec. Vol. 3, 105-112.

Papazzoni C.A. \& Trevisani E. (2006) - Facies analysis, palaeoenvironmental reconstruction, and biostratigraphy, of the "Pesciara di Bolca" (Verona, northern Italy): An early Eocene Fossil-Lagerstätte. Palaeogeogr., Palaeoclimat., Palaeoecol., 242 (1-2), 21-35.

Schwark L., Ferretti A., Papazzoni C.A. \& Trevisani E. (2009) - Organic geochemistry and paleoenvironment of the Early Eocene "Pesciara di Bolca" Konservat-Lagerstätte, Italy. Palaeogeogr., Palaeoclimat., Palaeoecol.,273 (3-4), 272-285.

Serra-Kiel J., Hottinger L., Caus E., Drobne K., Ferràndez C., Jauhri A.K., Less G., Pavlovec R., Pignatti J., Samsó J.M., Schaub H., Sirel E., Strougo A., Tambareau Y., Tosquella J. \& Zakrevskaya E. (1998) - Larger foraminiferal biostratigraphy of the Tethyan Paleocene and Eocene. Bull. Soc. Geol. Fr., 169, 281-299.

Sorbini L. (1972) - I fossili di Bolca. Museo Civico di Storia Naturale di Verona, Verona, 133 pp. 